\section{ELECTRONS AND MATTER.}

THE inaugural address on "Electronen en Materie," delivered by Prof. C. H. Wind upon taking the chair of mathematical physics and theoretical mechanics at the University of Utrecht on February 20 of this year, has lately been published (Levden: A. W. Sijthoff) Beginning with a brief account of the gradual development of the conception of electrons, mainly through the works of H. A. Lorentz, and of its sudden corroboration after the discoveries made by Zeeman and Röntgen, the address goes on with an exposition of the notions of ether, electric displacement, electrons, and magnetic force in their present form, and traces the way to the idea of an electromagnetic mass of the electrons.

The measurements made by Kauffmann, though showing that these particles of matter probably do not possess any mass besides this electromagnetic one, of course do not prove that the same should be the case with all other particles of matter in our universe, as Wien had suggested. Yet they make this suggestion-the basis of what the author calls an electron theory a outrance-to some extent a plausible one. Several of the brilliant and fascinating views which this ultimate theory opens having been expounded by $\mathrm{Mr}$. Balfour in his presidential address at the Cambridge meeting of the British Association, the present author directs attention to those concerning the structure of atoms, mechanism of radiation, and origin of chemical differences. He also enters into some more details, and assuming for a while that an atom of hydrogen consists of a single positive and a single negative electron, calculates that in this system the two components would be separated by a distance perhaps 100,000 times greater than the diameter of the largest of them, and that there must be stored up in the atoms constituting one gram of hydrogen an amount of energy equivalent to that required by a mail steamer to cross the Atlantic ten times.

Poincaré has raised several serious objections against the theory. Some of these relate to the temperate electron theory only, and lose their weight as soon as the ultimate theory is adopted. To take an example. Poincaré does not feel satisfied with the changes of length in solid bodies owing to their motion through ether, as suggested by Lorentz and by Fitzgerald in order to explain the result of Michelson's experiments. Lorentz himself, however, has already shown that this hypothesis, though appearin rather bold at first sight, becomes plausible as soon as molecular forces and masses are supposed to be in the same way as electromagnetic ones affected by a translation through ether; and it is clear that this supposition is involved in that of all matter consisting of electrons, which therefore at once clears the way.

The second category of objections, those arising from the dependency of electromagnetic mass upon velocity and direction of motion, from so many instances of unequal action and reaction, from the violation even of the law of inertia, whenever electrons move with a higher speed than light, are, on the other hand, most serious in the light of the ultimate electron hypothesis, whereas the temperate theory has a way left open to dispose of them. The latter theory, indeed, does not deny the existence of matter apart from electrors and considers electromagnetic mass as something se:sndary. By assuming as constituents of ether hidfe:: inatter, obeying the classical principles just as well as ordinary or coarse niatter this theory will be able to accourt for every apparent deviation from the principles which by nathematical reasoning should be deducted as occurrins in ccarse matter.

But if by progress of experiment and theory the electron hypothesis in its ultimate form should continue to gain ground, if it should finally prove unavoidable to accept the view that matter consists entirely of electrons, then mass and momentum would cease to be what they are now in our ideas, quantities strictly invariable. There is no. denying that this would involve a serious change of our general conception of nature. For the predilection and confidence with which science has for centuries been aiming at a description of the physical universe in terms only of matter and motion were based chiefly-though half unconsciously - on the idea of mass and momentum being invariable elements of nature, images or pictures of inNo. I 875 , voL. 72] variable elements of reality itself. Now this idea, si fundamental to our whole mechanical conception of nature, would shrink into an illusion in the light of the new theory. Of course, there would be a great advantage also. Whereas it scems now almost hopeless to involve electromagnetic phenomena in a description in terms only of matter and motion, the unity desired in our picture of the physical world would then be secured by putting it in terms of electrons and motion.

\section{UNIVERSITY AND EDUCATIONAL INTELLIGENCE.}

WE learn from Science that an anonymous gift has been made to the Lebanon Valley College, Annville, Pa., of a hall of science to cost $16,000 l$.

Mr. F. R. B. Watson has been appointed assistant lecturer and demonstrator in engineering at the Merchant Venturers' Technical College, Bristol.

A Reuter message from New York states that the American General Education Board has received from Mr. John Rockefeller cheques to the amount of $2,000,000 l$. , in pursuance of his promise last June to give that amount in cash or securities for the endowment of higher education.

A PRIZE of $50 l$. out of the Gordon-Wigan fund will be awarded at the end of the Easter term, I906, for a research in chemistry, of sufficient merit, carried out in the University of Cambridge. The research may be in any branch of chemistry. The dissertation, with the details of the research, must be sent to the professor of chemistry not later than the division of the Easter term, rgo6.

THE year-book of the faculty of engineering of the University of Liverpool (1905-6) shows that the courses of study are so arranged as to afford a general scientific training for those intending to become engineers. The honours course affords opportunities for specialisation in a selected branch of the profession. The university training, which extends over three years, is preliminary to or supplementary of pupilage under an engineer or apprenticeship with an engineering firm.

IT is announced in Science that the University of Pennsylvania will receive $12,000 l$. from the estate of the late Prof. Maxwell Sommerville, who held a chair of archæology in the university. President Thwing, of Western Reserve University, we learn from the same source, has announced that $\mathrm{Mr}$. Andrew Carnegie has given 50ool. towards the establishment of a fund of $20,000 l$. for the endowment of a chair of political economy at Western Reserve University, to bear the name of the late Senator Hanna.

TuE Engineering and Mining Journal publishes the presidential address delivered by Mr. F. W. McNair before the Society for the Promotion of Engineering Education, in which he shows that the Amcrican mining schools have amply proved the necessity for their existence. From statistics of the six largest mining schools in America, he shows that the ratio of graduation to enrolment is increasing, that there is an enormous percentage increase in students enrolled, and that the mining school product is gradually taking the place of the so-called practical man. Dividing the twelve years available for comparison into three periods of four years, it is shown that the schools under consideration graduated one man to 3.6 million tons of the total mineral production during the first period, one to 10.2 millions in the second period, and one to 9.4 millions in the last period.

IN connection with the department of geography of the University of Cambridge, special public lectures will be delivered in the Michaelmas term by Sir Clements $R$. Markham, K.C.B., F.R.S., and Sir Archibald Geikie, F.R.S. The following courses, which are open to all students, whether members of the university or not, have also been arranged:-A general course in geography (with practical work) will be given by Mr. H. Yule Oldham; courses on the geography of Europe, on the principles of physical geography, and on the history of geographical discovery will also be given by Mr. Oldham. Dr. J. E. Marr, F.R.S., will lecture twice weekly on geomorphology; Dr. A. C. Haddon, F.R.S., will give courses on ethnology and on anthropogeography; and $\mathrm{Mr}$. 
A. R. Hinks will lecture on geographical surveying (with field work). The duties of the board of geographical studies, which is responsible for the general administration of the department, include the promotion of geographical study and research within the university, the provision of instruction in the several branches of geographical science, the administration of the geographical education fund, and the publication of schedules defining the range of the geographical examinations for degrees and diplomas of the university in geography.

THE development and strengthening of the relation which the work of technical institutes and evening classes bears to the practice and commercial aspects of our industries are undoubtedly necessary parts of further industrial progress. For this reason we welcome a recent circular issued by the Board of Education to the inspectors of these educational institutions. The Board recognises the existence of a great variety in the character and amount of the cooperation between employers of labour on the one hand and the managers of technical institutions and evening schools on the other, and in its circular gives a short account of a few typical examples with a view of showing inspectors and others the kind of work which can be done with advantage in this direction. It is true that the details of such cooperation must vary from place to place in accordance with the special requirements of each important industry, but unless it exists in one form or another full advantage will not be derived from our expenditure on technical education. The circular proceeds to give a helpful résumé of what has been done to encourage artisans in their studies by means of the payment of fees and the award of prizes, by increases of wages, by allowances of time for attendance at classes, and by providing opportunities for higher instruction. The circular may be commended to all employers of labour who desire that the workmen of this country may be put into the way of competing on equal terms with those of other countries.

ON Friday last Lord Rosebery, as Chancellor of the University of London, opened the Goldsmiths' College at New Cross, formerly the Goldsmiths' Institute. The development of Polytechnics under the London County Council led the Goldsmiths' Company to reconsider the constitution of the institute, which had been carried on by the company since 1888 ; and last year the buildings were presented by the company to the University of London, with an unoccupied adjoining site of four and a half acres, and an endowment of $5000 l$. a year for five years. An additional sum of 50ool. was given by the company to enable the university to carry on evening classes during 1904-5, in cooperation with the London County Council. Under the new scheme the institution has become the Goldsmiths' College, University of London, and its functions are chiefly those of a day training college for elementary teachers. 'These students will take the ordinary two years' course provided by the regulations of the Board of Education, and will not prepare for a university degree; but the evening class work in science and engineering will still lead up to university degrees. In the course of his remarks at the opening ceremony, Lord Rosebery said:- "The University of London is spreading itself over the metropolis. It is not too much to say that, though we cannot say that it will soon spread itself over the Empire, we may at least say that it will very soon appeal to every portion of the Empire. It is a young university. It deals with comparatively new branches of learning. It deals with the practical and the concrete, rather than with the ancient and the abstract. In that respect there is a marked difference between it and those ancient universities to which some of us owe a loyal and filial allegiance which cannot be obliterated by any newer loyalty or allegiance. The newer universities must be content, and wisely content, with something which is not antiquity, and is not tradition, but may be more immediately useful and practical than either antiquity or tradition. We, placed in the largest community in the world, with our hands, so to speak, on the very heart of the Empire, living among new wants and new aspirations, meeting new needs and new acquirements, ready, as I hope, to face the exigencies of to-day and tomorrow, are the university of the future, though we cannot trace our antiquity back to the hoary past."

NO. I 875 , VOL. 72$]$

\section{SOCIETIES AND ACADEMIES.}

\section{LONDON.}

Royal Society, June 8.- "The Synthesis of a Substance allied to Adrenalin." By H. D. Dakin. Communicated by Prof. E. H. Starling, F.R.S.

The paper contains an account of attempts to synthesise adrenalin-the physiologically active principle of the suprarenal gland. Adrenalin is commonly regarded as a secondary alcohol of the formula

\section{$\mathrm{C}_{6} \mathrm{H}_{3}(\mathrm{OH})_{2} . \mathrm{CH}(\mathrm{OH}) . \mathrm{CH}_{2} \mathrm{NHCH}_{3}$.}

The corresponding ketone may be prepared by acting upon chloracetylcatechol with methylamine, and is a crystalline substance forming stable crystalline salts. The ketone may be reduced electrolytically, and the product may have the structure assigned to natural adrenalin. Although the synthetical base has many chemical and physiological properties in common with adrenalin, it probably is not the racemic form of the latter substance. The base forms extremely deliquescent salts which are unstable in hot solution; on addition of ammonia to aqueous solutions of the salts, the free base is precipitated in the form of a greywhite amorphous precipitate which is extraordinarily unstable in the dry state. Owing to experimental difficulties, satisfactory analytical and molecular weight determinations have not yet been made.

A close physiological relationship between the natural and synthetical bases is shown by the fact that, in the case of a rabbit, intravenous injection of less than $0 \cdot 000001$ gram is followed by a marked rise in arterial blood-pressure.

A base which is probably identical with the substance above described has been obtained by acting upon methylaminoacetylcatechol with aluminium and mercuric sulphate (D.R.-P. 157,300 ), and it is assumed to be a secondary alcohol. If this be correct, the formula for natural adrenalin will require modification, but more experimental evidence is needed before the question can be settled.

July r.-." On the Influence of Coilisions and of the Motion of Molecules in the Line of Sight, upon the Constitution of a Spectrum Line." By Lord Rayleigh, O.M., F.R.S.

Apart from the above and other causes of disturbance, a line in the spectrum of a radiating gas would be infinitely narrow. A good many years ago, ${ }^{1}$ in connection with some estimates by Ebert, the author investigated the widening of a line in consequence of the motion of molecules in the line of sight, taking as a basis Maxwell's well known law respecting the distribution of velocities among colliding molecules, and he calculated the number of interference bands to be expected, upon a certain supposition as to the degree of contrast between dark and bright parts necessary for visibility. In this investigation no regard was paid to the collisions, the vibrations issuing from each molecule being supposed to be maintained with complete regularity for an indefinite time.

Although little is known with certainty respecting the genesis of radiation, it has long been thought that collisions act as another source of disturbance. The vibrations of a molecule are supposed to remain undisturbed while a free path is described, but to be liable to sudden and arbitrary alteration of phase and amplitude when another molecule is encountered. A limitation in the number of vibrations executed with regularity necessarily implies a certain indeterminateness in the frequency, that is, a dilatation of the spectrum line. In its nature this effect is independent of the Doppler effect-for example, it will be diminished relatively to the latter if the molecules are smaller; but the problem naturally arises of calculating the conjoint action of both causes upon the constitution of a spectrum line. This is the question considered by Mr. C. Godfrey in an interesting paper, ${ }^{2}$ upon which it is the principal object of the present note to comment. The formulæ at which he arrives are somewhat complicated, and they are discussed only in the case in which the density of the gas is reduced without limit. According to the view of the 1 Phil. Mag., vol. xxvii., p. 298, 1880; "Scientific Papers," vol. iii., p. 258 . p. 258 . On the Application of Fourier's Double Integrals to Optical
Problems," Phil. Trans., A, vol. cxcv., p. 329, 1899 . 